The Geneva Papers on Risk and Insurance, 19 (No. 71, April 1994) 156-177

\title{
Theories of Regulation: Some Reflections on the Statutory Supervision of Insurance Companies in Anglo-American Countries
}

\author{
by M. B. Adams* and G. D. Tower**
}

\begin{abstract}
The paper evaluates the regulation of insurance markets by utilising three strands of regulation theory - public interest theory, capture theory and the economic theory of regulation. The paper seeks to explain why the insurance industry in some Anglo-American countries, such as Australia, is subject to stricter statutory control than in other AngloAmerican countries, like New Zealand.

Our analysis suggests that the economic regulation model offers the most appropriate framework for explaining different regulatory environments in countries because of its greater explanatory and predictive power. Six hypotheses drawn from economic regulation theory are put forward. They are proposed in this paper as a preliminary step which may assist in the conduct of future empirical research into the regulation of insurance markets.

\section{Acknowledgements}

The authors would like to express their appreciation to Hector Perera, Kathy Petroni, Mike Pickford, Asheq Rahman and Malcolm Smith for their comments on earlier drafts of this paper. However, the authors are solely responsible for any errors or misstatements which may remain. Finally, the financial support of Price Waterhouse is also acknowledged.

\section{Introduction}

All Anglo-American ${ }^{1}$ countries have laws regulating the business conduct and financial reporting of insurance business, although the exact nature of regulation varies between markets (Ellis, 1990, p. 277). Some of the salient differences in the regulatory regimes found in Anglo-American countries are outlined in Table 1, and eloquently testify to the

* Lecturer, Department of Accountancy, Massey University, Palmerston North, New Zealand.

** Senior Lecturer, School of Economics and Commerce, Murdoch University, Perth, Australia.

1 Anglo-American countries include Australia, Britain, Canada, Ireland, New Zealand and the United States of America. These countries are considered by researchers (e.g. Hofstede, 1980) to have similar business and legal structures by virtue of a like socio-political history bounded by the English language. Although the degree of regulation varies between Anglo-American countries, they are all reported to be less strictly supervised than in other parts of the world, such as Western Europe. For example, in Anglo-American countries, premiums and profits are generally not regulated (e.g. Finsinger and Pauly, 1986, pp. 12-13).
\end{abstract}




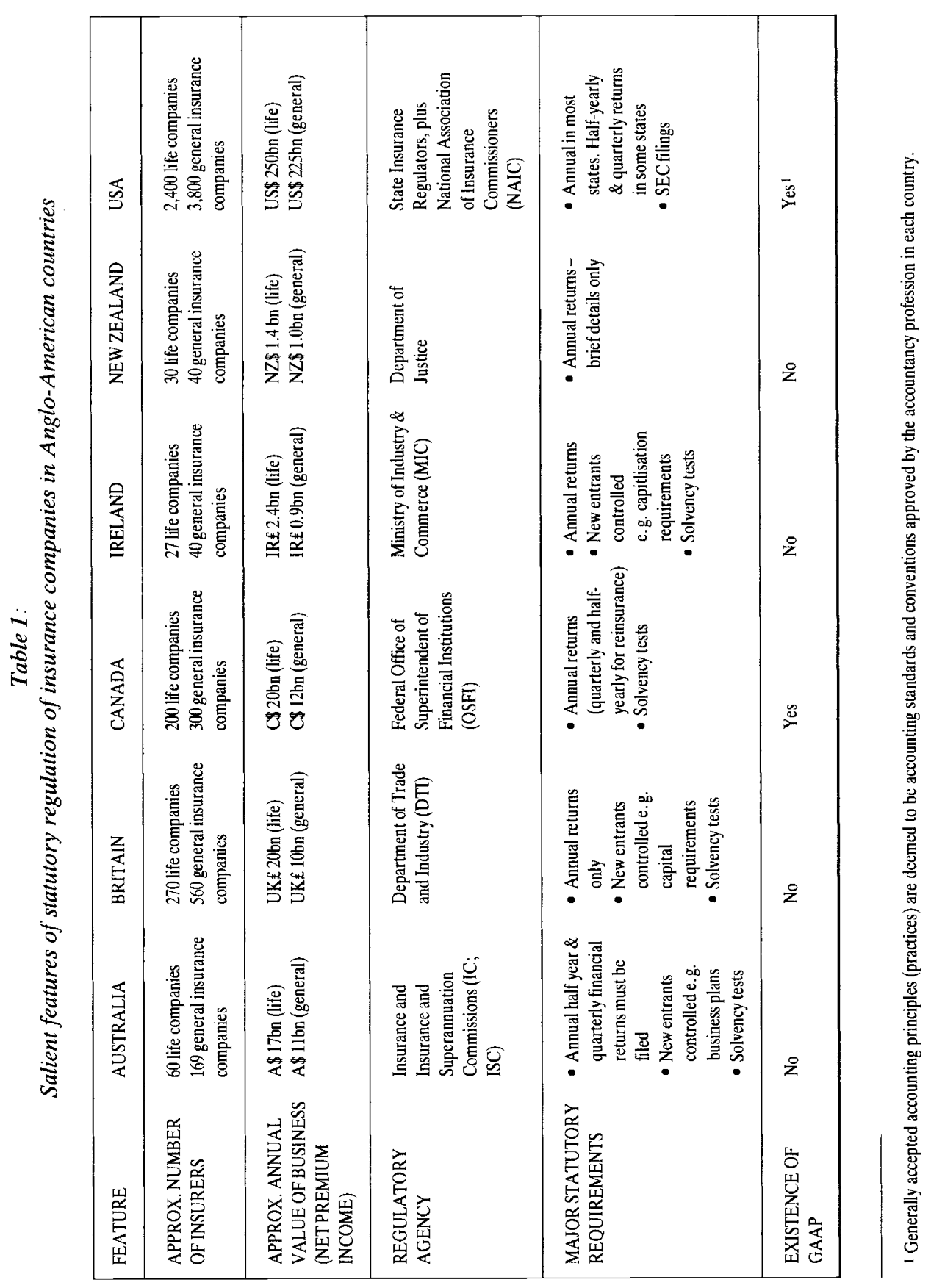




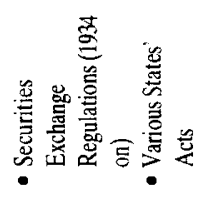

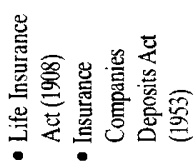

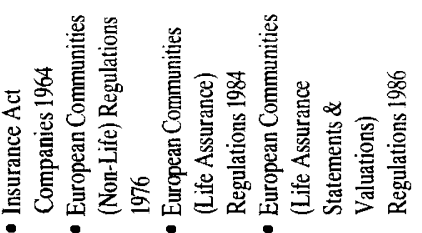

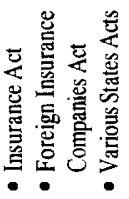

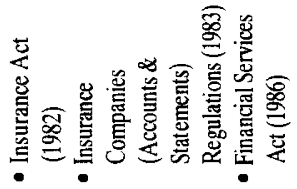

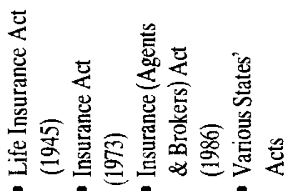

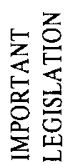

留

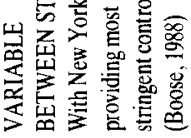

ठํㅗㅇ

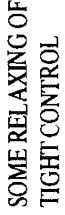

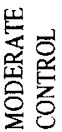

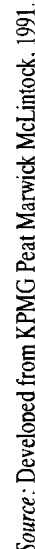


contrast between the tight supervision of insurance companies in Australia and the relatively unregulated insurance market in New Zealand.

For example, in Australia, statutory provisions ${ }^{2}$ require all insurance companies to: (a) submit a business plan with the regulatory authority, the Insurance and Superannuation Commission (ISC); (b) to comply with statutory restrictions on the use of accumulated funds; (c) maintain statutorily prescribed minimum levels of solvency; and (d) to file quarterly, half-yearly and annual business returns to the ISC, for solvency monitoring and control purposes. In contrast, insurance companies in New Zealand are not subject to such requirements. This situation has led commentators to remark that New Zealand-based insurance companies operate in what is probably the least regulated insurance market in the western world (Insurance Council of New Zealand, 1991, p. 15). The marked difference in regulatory regime between the Australian and New Zealand insurance sectors is also inconsistent with the sentiments of the 1983 Closer Economic Relations (CER) agreement which seeks to harmonise law and business practices between Australia and New Zealand.

Table 1 also highlights that the sizes of insurance markets vary immensely from the United States of America (USA), the largest insurance market with over six thousand firms transacting insurance, to New Zealand and Ireland, with approximately seventy life and general insurance companies each. However, it would appear that size of insurance market per se is not in itself a factor which necessarily explains the degree of regulatory control exercised by government. For instance, Ireland has an insurance industry of comparable size to New Zealand, but it has a much tighter regulatory regime, which is largely modelled on British - and to some degree, the generally more stringent, European Economic Community (EEC) - regulations. The Canadian insurance market has a well established regulatory regime which is influenced by both British and US regulatory systems. However, Canada is reported to be gradually implementing measures aimed at deregulating the insurance markets and widening investment and business freedom, particularly with the USA (KPMG Peat Marwick McLintock, 1991, p. 65). Furthermore, the domestic insurance markets in all Anglo-American countries have been well-established since the mid-nineteenth century (e. g. Nobbs, 1983, p. 463). Therefore, the length of time that an insurance market has been established in a country does not appear to explain differences in regulatory environment.

The purpose of this paper is to seek explanations as to why some Anglo-American insurance markets are more tightly regulated than others. The exercise should help researchers to better understand the nature of insurance markets and assist them to predict the likelihood, and potential impact, of statutory and regulatory initiatives. Section 2 of the paper analyses the rationale for insurance company regulation and the counter-arguments supporting the existence of free markets. Section 3 examines aspects of insurance company regulation by reference to three strands of regulation theory - public interest theory, capture theory and economic regulation theory. This section concludes that economic regulation theory offers the most appropriate framework for explaining the regulation of in-

2 The principal statutes governing general insurance in Australia are the Insurance Act 1973, and for life insurance, the Life Insurance Act 1945. In New Zealand, insurers are regulated by the Life Insurance Act 1908 and the Insurance Companies Deposits Act 1953. Regulations relating to compulsory investment requirements were revoked in 1985 by the government. 
surance markets. Section 4 presents six hypotheses drawn from economic regulation theory which can be subject to empirical testing. Finally, section 5 draws together some brief conclusions concerning the utilisation of the economic regulatory model in future research.

\section{Rationale for regulation}

Mitnick (1980, p. 5) defines regulation as "... the intentional restriction of a subject's choice of activity by an entity not directly party to or involved in the activity." Wilson (1974, p. 138) considers that the concept of regulation stems from either political motivations, such as a desire to re-distribute wealth; or from economic reasons, such as intervention to correct market imperfections, like the abuse of monopoly power. Wilson suggests that whatever the reason, political or economic, business regulation is not an inevitable event, but a process which derives from a variety of prerequisite causes and exists for some explicit purpose.

Free market theory argues either explicitly or implicitly that regulation is unnecessary because it hinders the efficient operation of markets. This body of theory is based on the efficient market hypothesis [EMH] (Rahman, 1992, p. 91) and rejects the view that government intervention is needed to rectify market imperfections. The EMH postulates that an optimal level of information is disclosed to buyers by suppliers through the interplay of the price mechanism and that state intervention in the market is, consequently, unnecessary.

Proponents of unregulated environments support the view that the free market provides an efficient mechanism for the determination of optimum information which reflects the cost-benefit functions to management of generating such information (Rahman, 1992, p. 94). Adherents of the free market approach argue that the regulation of insurance companies limits "... the choice available to the policyholder and (increases) the cost of insurance without offering adequate compensating advantages" (Ford, 1974, p. 55). However, according to Rahman (1992) the major drawback of anti-regulation models is their failure to explain why, and by whom, regulation is sought in industrial markets. He states that,

“... even though evidence from EMH studies tends to negate the market failure argument, those studies overlook the fact that regulation is demanded and supplied... All (efficient market explanations) have ignored the presence of other markets - the market for... regulations, and the behavioral aspects of its participants. Therefore, their regulatory implications are weak predictors.." (p. 106).

Beaver (1981, pp. 187-196) offers three main arguments supporting the case for business regulation: (a) the existence of inadequate incentives for participants to provide legitimate user groups with information; (b) the unequal possession of information among participating groups in the market; and (c) the tendency for industry groups to purposefully suppress the production of unfavourable information in unregulated environments. Mitnick $(1980$, p. 290) argues that incentives for regulation exist where state intervention can help to rectify market malfunctions of socially undesirable activity, such as industrial pollution. Table 2 below summaries Mitnick's $(1980$, p. 290$)$ views where regulation emanates largely from the political desire to protect the public interest from market failures.

In describing the motives behind the statutory regulation of insurance companies, Meier (1991, p. 701) contends that regulators have five main objectives as follows: (a) to 
Table 2:

Rationales for regulation

a To correct intentional activity that:

(a) is judged desirable in ideal situations but malfunctions in practice ;

(b) is judged undesirable with respect to the public interest.

Under 1:

Intermediate goal sets are considered important :

Therefore, regulate where:

1. competition can't survive

2. competition exists, but because of imperfections, does not get competitive results.

Possible defects:

(a) buyer ignorance;

(b) excessive risk ;

(c) discriminatory competition;

(d) hurtful competition.

3. competition exists, but other policies oppose reliance on it.

\section{b To control unintentional by-products of activities (such as externalities *)}

Source: Adopted from Mitnick (1980, p. 290).

* The presence of externalities in the marketplace is advanced as a possible cause of market failure. Beaver (1981, p. 189) defines externalities as "... actions of one party [which] have effects on other parties who are not charged (or compensated) via the price mechanism".

monitor corporate solvency; ${ }^{3}$ (b) to ensure fair trading; (c) to regulate entry to markets; (d) to promote price stability; and (e) to satisfy social objectives. These regulatory objectives are briefly discussed below.

${ }^{3}$ Some commentators (e.g. Ford, 1974, p. 54) suggest that solvency control not only aims to ensure that insurance companies are able to fulfil their contractual obligations, but also to satisfy the "reasonable expectations" of policyholders. This would include considerations such as the achievement of corporate success, and the overriding need for generations of policyholders to be treated equably in the distribution of bonuses. 
Batten (1981) asserts that solvency control of insurance companies, particularly life offices, is a primary objective of the regulatory agency because "... like banks, life offices operate with a high degree of public trust ... selling the promise of future security to a large proportion of the population..." (p. 68). Therefore, the insolvency of a life office can become a salient political issue and could commit the state to high unanticipated costs, such as the costs of judicial management of insolvent firms. It could also ultimately lead to the imposition of stringent regulations on the insurance industry by government.

The regulatory objective of fair trading seeks "... to prevent information asymmetry from distorting the market to the disadvantage of the consumer" (Meier, 1991, p. 702). Frequently, fairness becomes a consumer protection issue covering consumer rights, investment securities legislation and the promotion and selling of insurance company products. For example, Britain has instituted extensive fair trading legislation through the Financial Services Act 1986. This Act provides for the authorisation, monitoring and control of investment and insurance business through self-regulatory organisations (SROs), directly responsible to a government body the Securities Investment Board (SIB). The scope of the work of the SROs is very broad and includes such issues as advertising and promotion, conduct of investment business, payment and reporting of brokers' commission, and the training and supervision of financial advisers.

However, considerations of fairness might not relate just to consumer matters. For example, Demsetz and Lehn (1985, p. 1174) propose the regulator-monitor hypothesis which argues that external regulation can help to promote the interests of owners of the firm by acting as a substitute for ownership control. They suggest that regulation helps firms to reduce their agency costs, ${ }^{4}$ and to report better financial performance. Support for the regulator-monitor hypothesis is provided by empirical evidence obtained from the US life insurance industry by Boose (1988). She concludes that proprietary life insurance companies operating in the tightly regulated environment of New York State report lower expense levels than other life offices in the country because the "... regulator can substitute for stockholders in monitoring the agency costs imposed as operating expenses" (p. 167).

Another reason supporting the case for regulation is that regulators can improve access to the insurance market by monitoring monopoly practices on price and encouraging competition through the removal of barriers to entry. Alternatively, market access can be controlled by regulators through the establishment of licensing procedures. Licensing procedures also provide a control against the risk of insolvency by, for example, requiring prospective entrants to submit a business plan and to meet prescribed solvency ratios prior to authorisation. In the USA, many state regulators try to protect local insurance firms by prohibiting the operation of insurance companies owned by foreign governments. In Australia, foreign owned insurance companies must demonstrate substantial net economic benefits to the Australian economy before authorisation to transact business is granted (Ellis, 1990, p. 280). Furthermore, Barrow and Ferguson (1984) argue that the growth of composite insurance companies engaged in both life and general insurance business should

\footnotetext{
${ }^{4}$ Agency theory postulates that business practices, such as financial reporting, enable the owners (principals) of a firm to monitor the behaviour of managers (agents) who have been charged with using resources. The relationship between principals and agents is a contractual one which results in "agency costs" for both parties. For instance, the costs associated with the preparation and publication of financial statements is a monitoring cost borne by the owners (Watt and Zimmerman, 1986).
} 
result in tighter regulation because of the risk that "... the long-term business of an insolvent composite company might be run off whilst the short-term business was wound up" (p. 238).

Price stability, through the control of premiums, might be another important goal of insurance company regulators. Research by Mayers and Smith (1988) in the North American property-casualty insurance sector, found that fluctuating pricing strategies can exist not only as a response to market trends, but also as a result of different agency costs between mutual and proprietary insurance companies. ${ }^{5}$ They argue that in proprietary companies, shareholders “... have incentives to increase the value of their claims at the expense of policyholders after policies are sold .. and [therefore shareholders] can sell insurance for higher prices" (p. 356). This means that price regulation might be introduced to help protect the interests of consumers from unfair pricing strategies.

Regulators might also seek social, as well as economic, objectives. For instance, insurance companies may be required by regulation to invest their funds in ways that they would not normally do. For example, up until February 1985, life offices in New Zealand were required under compulsory investment regulations to invest 31 per cent of their capital in public sector investments. This requirement was removed as part of the political initiatives started in 1984 to deregulate the New Zealand financial market. However, the former policy did reflect the desire of the government of the time to direct insurance company investment into the public sector of the economy. In Britain, regulators have been content not to adopt and interventionist approach with regard to such matters as prescribing life insurance company investment, provided life insurance companies act in a socially responsible manner (Tapp, 1986, p. 35).

\section{Evaluation of regulation theories}

Posner (1974, pp. 335-343) examines three strands of regulation theory which seek to explain the reasons for government intervention in markets. These are: (a) public interest theory; (b) capture theory; and (c) the economic theory of regulation.

Public interest theory adopts the view that regulation results when government is spurred into action either by the desire to promote social welfare, or by some critical event, such as corporate failure. Capture theory asserts that regulatory agencies tend to be taken over by the group(s) which government intervention is originally designed to regulate. The economic theory of regulation is derived from Stigler (1971), and includes many of the features of both public interest theory and capture theory (Posner, 1974, p. 343). For instance, it incorporates some of the salient precepts of neo-classical economics, such as rational and self-motivated behaviour by producers and consumers, and treats regulation as a product, subject to the forces of the market and the demonstration of public choice. Each of these three variants of regulation theory are summarised in Table 3, and examined below, with reference to examples drawn from the insurance sectors in various Anglo-American countries, below.

\subsection{Public interest theory}

Public interest (or market failure) theory (PIT), postulates that government regulation is primarily a re-distributive social welfare device which seeks to correct the misallocation holders.

${ }^{4}$ Mutual companies are owned by policyholders, while proprietary companies are owned by share- 


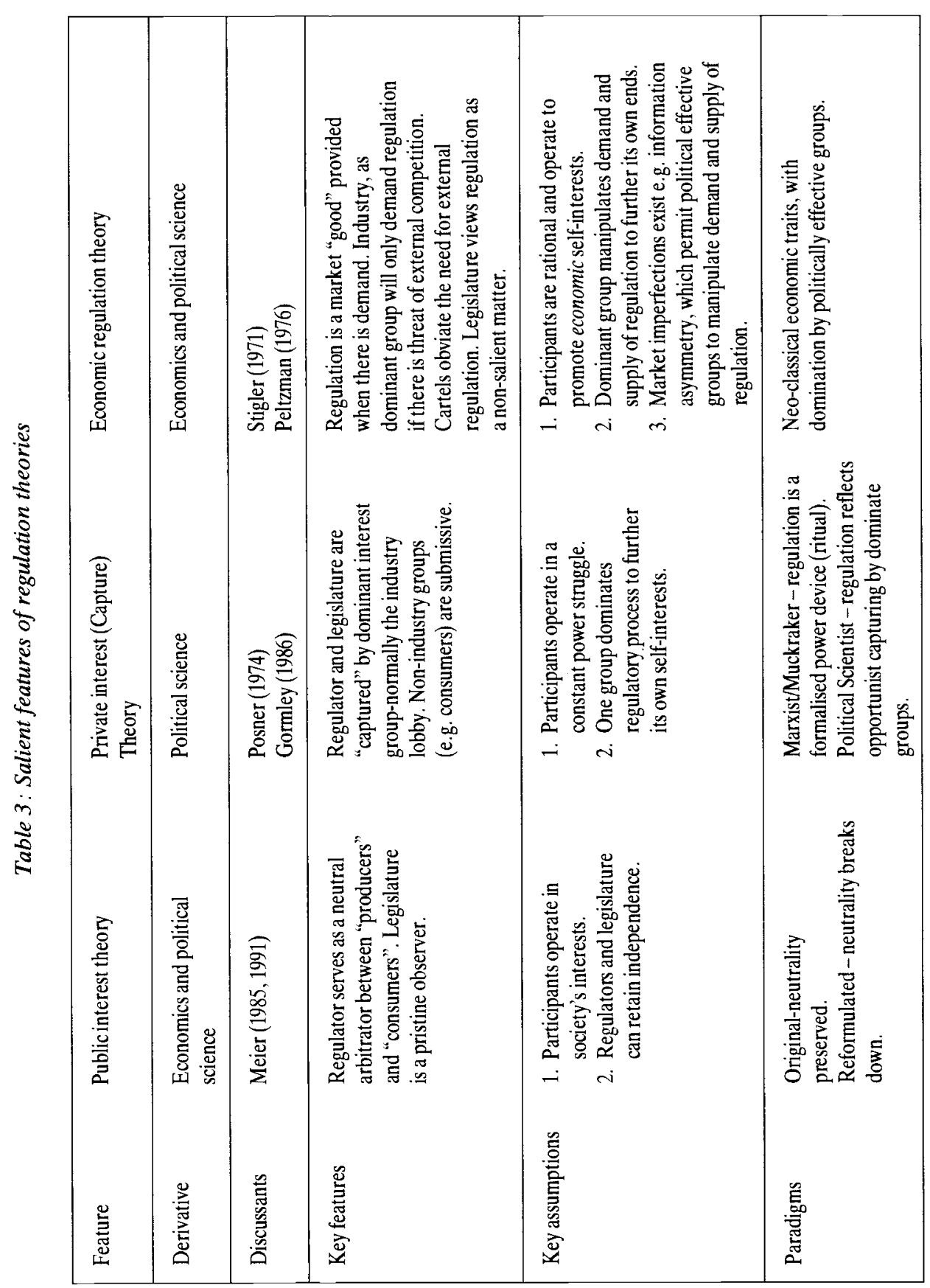


or resources stemming from the failure of the market or from some political crisis (Wilson, 1974 , p. 138). For instance, in the case of the British insurance market the collapse of the Vehicle and General Insurance Company in 1971 was the event chiefly responsible for the tightening up of insurance company legislation and regulatory procedures (Harte and Macve, 1991, p. 353). Proponents of PIT argue that the regulatory process helps to promote price competition by, for example, removing restrictive trade practices commonly associated with the abuse of monopoly power. In its original form, PIT viewed regulators as independent and neutral arbitrators responding to the demands of the public to correct inefficient and/or inequitable market practices (Peltzman, 1976, p. 212). The relationship between participants in the regulatory model envisaged by PIT is illustrated in Figure 1 below.

Figure 1:

Public interest theory: A conceptual model

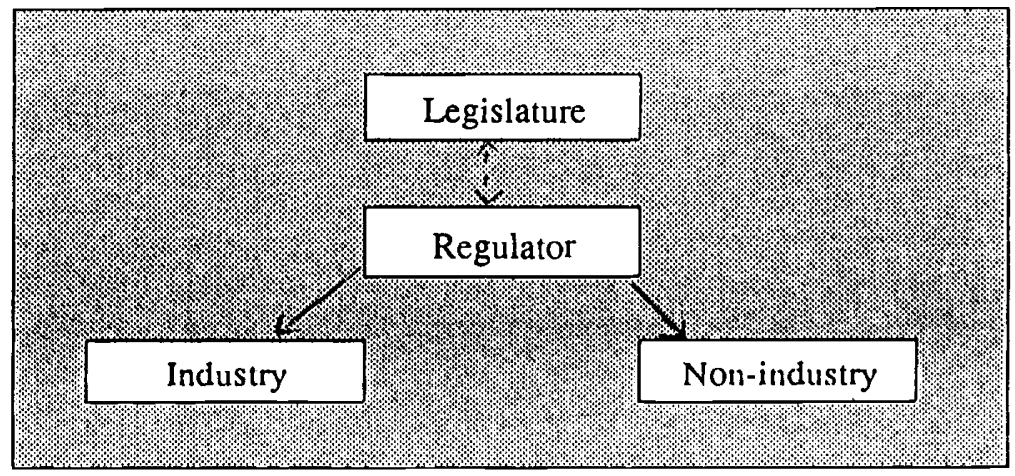

\begin{tabular}{||l|l||}
\hline \multicolumn{1}{|c|}{ Participant } & \multicolumn{1}{|c|}{ Public Interest Theory } \\
\hline Regulator & Neutral Arbitrator \\
\hline Industry Lobby & $\begin{array}{l}\text { Free Market Player, Protected } \\
\text { by Regulator }\end{array}$ \\
\hline $\begin{array}{l}\text { Non-Industry Group e.g. } \\
\text { Consuners }\end{array}$ & $\begin{array}{l}\text { Free Market Player, Protected } \\
\text { by Regulator }\end{array}$ \\
\hline Legislature & Pristine Observer \\
\hline
\end{tabular}

The statutory regulation of insurance companies has traditionally been promoted as an exercise safeguarding the public interest - a view couched in the long-standing principle of 
"freedom with publicity". ${ }^{6}$ However, Posner (1974, p. 335) reports how in reformulated versions of PIT, the neutrality of regulators frequently breaks down to the detriment of the public interest. Meier (1991, p. 708) proposes three possible reasons for the failure to protect and to promote the public interest: (a) bureaucratic ineptitude; (b) the lack of skills and resources by the regulating agency; and (c) the complexity of technical issues.

Firstly, Posner (1974, p. 337) considers that the regulatory agency will often become the victim of ineptitude through the inertia and disinterest of regulator's staff. In the New Zealand context, the failure of the regulatory agencies to predict financial difficulties in insurance companies ${ }^{7}$ might be interpreted as mismanagement by, or lack of resources in, the regulatory agency, the Department of Justice. However, Wilson (1974, p. 147) attributes bureaucratic failures not so much to management incompetence as to the inflexible and inappropriate constraints of the political system within which bureaucrats have to operate. Secondly, political scientists (e.g., Mitnick, 1980; Rourke, 1984) argue that the functions of regulatory agents break down because of a lack of adequate financial and staff resources. Meier (1991) cites evidence from the US insurance sector which suggests "... that lack of regulatory [resource] capacity was a major reason for the rise in insurer insolvencies in the late 1980's" (p. 703). Indeed, in an in-depth study of the function of the Registrar of Companies in New Zealand, Hall $(1987, \mathrm{p} 122)$ reported that the regulatory agency is underresourced in terms of funds, staffing and expertise to effectively perform its supervisory and regulatory responsibilities. A third reason why regulatory agencies might fail to protect the public interest is that the subject matter being regulated is technically too complex. This is particularly so in the life insurance industry, where insurance contracts are frequently of a sophisticated and complex technical nature (Meier, 1991, p. 708), Smith (1986) puts forward a fourth reason why regulators might not serve the public interest: "... that regulators are not benign forces interested only in social-welfare maximization. Rather, they have their own agendas and use their discretion in the regulatory process in their own selfinterest" (p. 709). Mayers and Smith (1981, p. 431) suggest that regulators might introduce extensive rules and regulation in order to satisfy their political masters and promote their own self-interest, for example, by increasing staff numbers and enhancing job security. The result of this behaviour will thus be an increase in bureaucracy which might not be in the public interest.

In his evaluation of the usefulness of PIT, Posner (1974, pp. 336-340) concludes that it is deficient as an explanatory and predictive framework because it fails to explain adequately behaviour observed in markets. He also challenges the tenets of PIT which assume that: (a) markets are apt to function in an inefficient and inequitable manner, if left unregulated; (b) regulation is costless; (c) politicians perceive that the benefits associated with

6 The statutory control of British life insurance companies and life offices in the British Commonwealth is influenced by the prescriptions of the British Life Assurance Companies Act 1870. This Act established the principle "freedom with publicity" which reflects the legal view that regulation should promote the disclosure of information of life office activities deemed to be in the public interest, without inhibiting the economic operations of life offices (Fisher and Young, 1965, p. 32). The term "freedom with publicity" has, however, been criticised for its unclear meaning (e.g. Ford, 1974, p. 55). Tapp (1986, p. 35) considers that the operable principle is now "freedom with responsibility" in that government will only intervene in the insurance industry if companies are judged to be acting in a socially irresponsible manner.

${ }^{7}$ For instance, since 1989 , three life offices have become insolvent in New Zealand. These companies are Australasian Commercial Life, First Pacific Life and Super Mutual Ltd. 
intervention offset any harmful effects. Goodhart (1988, p. 31), commenting on the new regulatory proposal imposed by the British Financial Services Act 1986 on financial institutions, supports the idea that economic costs of regulation can be substantial and frequently can exceed the benefits. Peirson and Ramsay (1983, p. 293) dismiss the notion that governments are neutral observers who intervene to secure social welfare objectives, arguing that the public interest is often veiled in the pursuit of political self-interest. Mitnick (1980, pp. 278-279) also criticises PIT for the lack of a clear conception of the notion of public interest. Finally, Rahman (1992, p. 90) argues that PIT fails as a robust theoretical framework for two main reasons: (a) it does not take into account economic realities; and (b) it does not acknowledge that governments are composed of self-motivated interest groups.

\subsection{Capture theory}

Capture (or private interest) theory, is derived largely from the political science literature. It predicts that regulation is a partisan political process conferring benefits on politically effective groups which capture and dominate the regulatory process (Noll and Owen, 1983; Reagan, 1987). Posner (1974, p. 341) distinguishes between two paradigms within the general body of capture theory: (a) the Marxist/Muckraker view; and (b) the Political Scientist perspective.

The Marxist/Muckraker view, reflects the broader thinking of radical theorists who perceive that the regulatory process promotes the interests of capitalism and alienates the position of labour in the structure of society. Tinker $(1984$, p. 71$)$ argues that radical theories of the state provide alternative explanations for the level of, and changes in, the regulation of markets. Therefore, the relatively unregulated market and weak protection afforded to consumers in New Zealand (Adams, 1992, pp. 54-55) could be interpreted under a radical perspective as reflecting the dominance of capitalist corporate interests at the expense of the general public.

The privatisation of state insurers, prompted by political ideology, can also adversely affect social welfare. For instance, Finsinger and Pauly (1986, p. 5) suggest that public sector insurers can help curb the abuse of monopoly power by issuing business at breakeven premiums. Therefore, the recent privatisation of state insurance companies, as in New Zealand, ${ }^{8}$ could be interpreted as promoting private sector interests rather than the general public. Indeed, Merino and Neimark (1982, p. 34) attribute corporate disclosure regulation in the USA to significant events, or crises, in the development of capitalist society, such as the growth in share ownership. Furthermore, a Marxist interpretation to the development of insurance market regulation can be interpreted as a response to crises in capitalist society. For example, in their historical analysis of the statutory supervision of British life insurance market, Barrow and Ferguson (1984, p. 237) attribute the implementation of tighter regulation to crises, such as the collapse of two large life offices - the Albert and European life insurance companies in the late 1860's - and to the economic depression that followed the First World War.

\footnotetext{
${ }^{8}$ In New Zealand, government links with insurance business were severed in 1990 with the privatisation of the Government Life Office (now the mutual Tower Life) and the sale of the general insurance company, State Insurance, to the Norwich Union Group.
} 
Political scientists do not subscribe to the radical view that regulation reflects class conflict in society, but rather judges the regulatory process as the outcome of opportunistic capture by elite groups, which usually represent the industries that are regulated. Feroz (1987, pp. 8-9) considers that industry groups tend to be successful in capturing the regulatory process, and thereby, dominate other groups in society, because they have: (a) the economic resources; (b) an interest in the beneficial outcome; (c) sound organisational capabilities; and (d) industry-specific knowledge. The relationship between the various participants in the political science view of the regulatory capture model is illustrated in Figure 2 below.

Figure 2:

Capture theory: A conceptional model

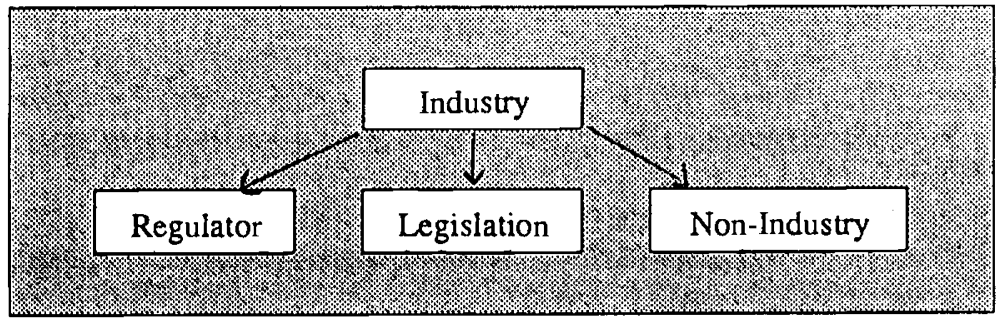

\begin{tabular}{||l|l||}
\hline \multicolumn{1}{|c|}{ Participant } & \multicolumn{1}{c|}{ Capture Theory } \\
\hline Regulator & Submissive Player \\
\hline Industry Lobby & Dominant Player \\
\hline $\begin{array}{l}\text { Non-Industry Group e.g. } \\
\text { Consumers }\end{array}$ & Submissive Player \\
\hline Legislature & Submissive Player \\
\hline
\end{tabular}

Stigler (1971, p. 5) considers that industry groups seek to capture the regulatory and/or legislative process for two main reasons: (a) to protect their market(s) from outside competition and the entry of new firms; and (b) to obtain state subsidies. Such action can adversely affect the interests of consumers, by restricting supply and increasing prices. To mitigate against the chance of less effective political groups like consumers being disadvantaged in the New Zealand insurance market, some commentators (e.g. Hunt, 1992a, p. 30) advocate that the government should appoint a well-funded, high profile and politically independent commission or board, like the Australian Insurance Commission (ISC), to regulate the industry. 
The life insurance industry possibly offers an example of capture by a professional group - the actuaries. Some countries - such as Australia and Britain - have an appointed actuary regime, under which each registered life office employs a member of the actuarial profession to provide a detailed annual report to the regulatory agency on the financial condition of the company. Johnston (1989) reports that the appointed actuary regime is "... a 'double harness' system with the regulatory authorities and the [actuarial] profession pulling together, and with significant responsibilities devolved to the actuarial profession" (p. 31). Johnston notes that through this regime, the actuarial profession exerts considerable influence over the regulatory process by virtue of its acknowledged expertise in life insurance business matters.

Some researchers (e.g. Gormley, 1986) suggest that the ability of industry groups to influence regulatory policy tends to increase the more complex and technical are the issues involved. Meier (1991, p. 709) proposes that politicians often find complex issues to be too costly to deal with, and will in consequence, perceive such issues to be politically unimportant. In such circumstances, it is predicted that politicians will tend to favour a process of self-regulation by the industry. This hypothesis seems to fit the New Zealand insurance regulatory regime where, to a large extent, self-regulation is promoted by the insurance industry, and where insurance issues have tended not to possess a high political profile. However, concerns of commentators (e.g. Reid, 1988; Wood, 1991) about industry-specific issues, such as the absence of generally accepted accounting principles (GAAP) for New Zealand-based insurance companies, is beginning to give insurance company financial reporting a much higher political profile than has hitherto been the case. Indeed, the New Zealand Financial Reporting Act 1993, (Clause 4) specifically provides for life insurance companies, as issuers of public securities, to comply with GAAP.

Despite the alleged capture by certain dominant industry groups of the regulatory process, some writers (e.g. Meier, 1985, 1991) suggest that the economic resources at the disposal of industrial groups do not always translate into equivalent political power. Meier (1991, p. 704) argues that this is particularly true of the insurance industry in the US. He attributes this to lack of mobilisation and incohesiveness within the insurance industry.

Meier (1991, p. 704) states that insurance companies are an ineffectual lobby group because they do not mobilise their economic resources towards developing political skills and expertise. In New Zealand, the life insurance industry, with invested funds amounting to nearly NZ $\$ 12$ billion, is indisputably an important contributor to the national economy and society (Carew, 1987, p. 67). However, the industry has generally failed to influence the government to modify its current free market policy in its favour on at least two major issues: (a) preventing the entry of banks and other financial institutions into the insurance market (Roberts, 1991, p. 6) ; and (b) persuading the government to introduce tax concessions for superannuation schemes (Ashton and St John, 1988, p. 30). Meier (1991, p. 705) also attributes the insurance industry's failure as an effective lobby group to intra-industry conflicts of interest. In New Zealand, the interests of the life insurance industry are represented by the Life Office Association, while the interests of fire and general insurers are promoted by the Insurance Council. These two organisations have separate policy agendas and political goals, and different administrative functions. ${ }^{9}$ Meier considers that incohesion

\footnotetext{
${ }^{9}$ For instance, the New Zealand Insurance Council monitors the solvency of fire and general insurance companies from returns filed with its members. The New Zealand Life Office Association has not to date considered such a requirement to fall within its sphere of responsibility.
} 
among insurance companies also emanates from the various product lines marketed by insurers in the same industrial group. For example, a life insurance company which sells a large number of superannuation products will have different policy interests from that of a life office which sells more conventional life insurance products.

Both the Marxist and Political Scientist versions of the regulatory capture model have been subject to criticism in the literature. For instance, Posner $(1974$, p. 341$)$ rejects the Marxist explanation of capture theory because regulation can also serve the interests of small businesses and individuals, and not just the interests of large corporate groups. Rahman (1992, p. 113) criticises the political scientist approach because it has insufficient explanatory and predictive power and that in addition,

"... no reason is suggested as to why the regulated industry should be the only interest group able to influence a regulatory agency... Lastly, it ignores a good deal of evidence that the interests promoted by regulatory agencies can also be in accord with those of other groups rather than that of the regulated firms alone."

\subsection{Economic theory of regulation}

Stigler (1971) refines and expands the tenets of capture theory into a reformulated theory of economic regulation based on the concept of public choice. ${ }^{10}$ This theory takes the view that regulation is an economic good whose allocation is governed by the laws of demand and supply (Posner, 1974, p. 344). The relationship between participant groups under economic regulation theory are illustrated in Figure 3 below.

On the demand side, the contention held by proponents of economic regulation theory, is that because industry groups possess more information than other groups, such as consumers and politicians, corporate interests tend to prevail in the market (Peltzman, 1976, p. 212). On the supply side, the economic regulatory model contends that regulation is supplied by policymakers as long as the demand from politically effective groups is greater than the opposition to it (Rahman, 1992, p. 115). Therefore, unlike PIT, economic regulation theory contends that state intervention does not seek to correct market inefficiencies and inequities, but like capture theory, it accommodates the notion that regulation exists to promote the economic interests of politically effective groups (Stigler, 1971, p. 3). This is particularly pertinent in the insurance industry where, as previously mentioned, the issues are often perceived by non-industry groups to be technical and complex. Finsinger and Pauly (1986, p. 6) note that the insurance industry might actively seek more regulation in order to foster goodwill with consumers, if there is a risk that consumers may perceive that lack of regulation will increase the chance of corporate failure. Furthermore, Munch and Smallwood (1980, p. 263) suggest that insurance companies might lobby for tighter regulation to discourage new entrants into the market in order to protect their economic position. Conversely, opposition to regulatory initiatives results if industry groups perceive that increased regulation will adversely affect their wealth.

The economic theory of regulation predicts that where the corporate lobby is dominant, demand for regulation will be at its highest where there are large numbers of firms competing in the market. Conversely, where there are relatively few firms in the market, and particularly where cartel arrangements are likely to predominate, the corporate lobby

${ }^{10}$ Mueller (1976) defines public choice as "... the economic study of non-market decision making or simply the application of economics to political science" (p. 395). 


\section{Figure 3:}

Economic regulation theory: A conceptual model

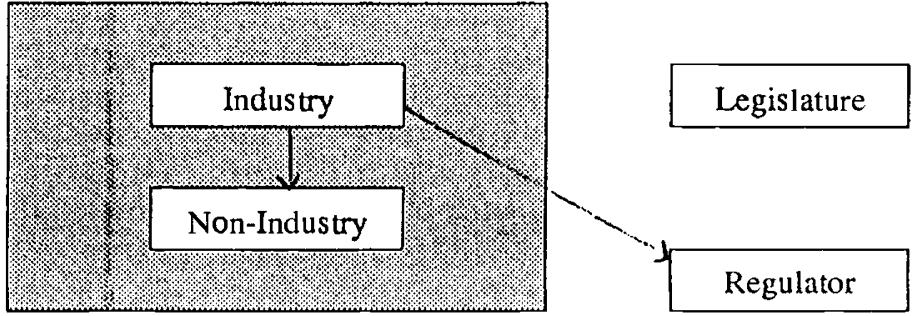

\begin{tabular}{||l|l||}
\hline \multicolumn{1}{|c|}{ Participant } & Economic Regulatory Theory \\
\hline Regulator & $\begin{array}{l}\text { Captured Player or replaced by } \\
\text { Cartels }\end{array}$ \\
\hline Industry Lobby & Dominant Player \\
\hline $\begin{array}{l}\text { Non-Industry Group e.g. } \\
\text { Consumers }\end{array}$ & Submissive Player ${ }^{1}$ \\
\hline Legislature & Non-Player ${ }^{2}$ \\
\hline
\end{tabular}

1. Meier (1991, p. 704) points out that in the insurance industry consumer groups often dominate the corporates lobby due to the insurance industry's lack of cohesion and poor political skills.

2. In practice, there is likely to be some statutory control, but such regulation is likely to be out-of-date and weak, as is the case, for example, with the NZ insurance industry.

will tend to favour self-regulation. Posner (1974, p. 347) suggests that this situation arises because cartelization offers firms a cost-effective substitute for regulation. In the New Zealand life insurance industry, where approximately 70 per cent of business is underwritten by five large subsidiary companies/branches (New Zealand Department of Statistics, 1991, p. 181), ${ }^{11}$ cartel arrangements could exist, and this might help to explain why the New Zealand insurance sector is, by international standards, an unregulated market. In contrast, other Anglo-American life insurance markets, such as those of Britain (Praetz, 1983, p. 383) and Canada (Kellner and Mathewson, 1981, p. 25), are less concentrated than the New Zealand life insurance market. Accordingly, this feature could suggest less scope for cartel self-regulation and it may account for the more stringent regulation in the British and Canadian insurance markets.

11 The five companies ranked in order of size of total assets are: Australian Mutual Provident (NZ $\$ 3.16$ bn), National Mutual (NZ $\$ 2.09 \mathrm{nb}$ ), Tower (NZ \$1.72 bn); NZI Life (NZ \$0.98 bn), and Prudential Assurance (NZ \$0.65 bn). All figures are obtained from the 1992 published New Zealand annual report and accounts. 
The New Zealand insurance sector provides further evidence which might suggest that the insurance industry has acted to play down politically sensitive issues by maintaining selfregulation through cartelization. Firstly, it can be argued that in New Zealand, larger insurance companies have sought recently to prevent corporate insolvency from becoming a political issue by voluntarily taking over the business commitments of smaller companies which have gone into receivership. ${ }^{12}$ Secondly, an initiative by the Life Office Association of New Zealand to provide a conciliation and arbitration service for the resolution of consumers complaints might be interpreted as a gesture by the life insurance industry to promote its own interests by minimising the risk of more direct (and potentially costly) consumer protection legislation on the industry. Thirdly, the New Zealand life insurance industry is heavily reliant on the reinsurance market. ${ }^{13}$ Mayers and Smith (1981, pp. 429-430) suggest that "... reinsurance is simply an institutional response to avoid bankruptcy ..." and arguably, it is a process which helps to prevent corporate insolvency from becoming a political salient issue. Mayers and Smith also predict that the incidence of reinsurance increases when there are large numbers of small companies and more mutual companies operating in the market. ${ }^{14}$ They also contend that reinsurance is favoured by the insurance industry because it is less costly than external regulation. Consequently, they suggest that reinsurance will be more common in relatively unregulated markets, such as the New Zealand insurance industry, than in more regulated environments. Reinsurance arrangements among the large companies may also strengthen cartelization in that, through reinsurance, smaller life offices can become "agents" for the larger companies.

In the economic theory of regulation, the goal of participants in the standard-setting process is to enhance the wealth and influence of its constituents. Therefore, the forces of demand and supply of a life insurance accounting standard can be interpreted in the context of self-interest between the various participating groups, in this case the accountancy and actuarial professions, which both have economic incentives to participate in the standardsetting process. Procrastination in the development and promulgation of a life office accounting standard (e.g. Krumpes, 1992, p. 24) may reflect the lack of congruence between the views of the two participant professional bodies..$^{15}$

Posner (1974, pp. 341-344) considers that economic regulation theory has greater explanatory power than either PIT or capture theory because it : (a) discards the assumption of pristine legislative purpose in correcting market failure ; (b) replaces the capture metaphor

\footnotetext{
12 For example, in New Zealand, the business of the troubled AA Mutual life office was taken over by Sun Alliance in 1991. However, Barrow and Ferguson (1984, p. 234) point out that large life offices might be reluctant to continue amalgamating with troubled firms since it will inevitably jeopardise their financial soundness.

${ }^{13}$ Reinsurance is a procedure whereby the original insurer relieves itself of part, or all, of an insurance risk by passing it on to another insurance company. In New Zealand, life insurance can be placed with either one of the larger life offices, or with a specialist reinsurance company. Most business underwritten by the smaller life offices in New Zealand (i.e. firms with life funds valued at less than $\mathrm{NZ} \$ 25$ million) is reinsured.

14 Mutual companies may view reinsurance as a means of expansion given their inability to raise finance on the capital markets.

${ }_{15}$ A possible explanation for the reported conflict could be that each professional body adopts a different paradigm position with regard to financial reporting. For instance, accountants tend to view financial statements primarily as investment decision documents, while actuaries tend to view financial reports as solvency documents which serve the interests of policyholders.
} 
by the concepts of demand and supply of regulation; (c) assumes the more tenable view that groups participate in the regulatory process to further their own interests; and (d) explains why and how regulations occur through cartel arrangements and the domination of the regulatory process by politically effective groups. Rahman (1992, p. 163) acknowledges that interplay of demand and supply in a particular regulatory market is dependent on how long the particular regulatory process has been in place. However, because the economic theory of regulation accommodates the concepts of self-interest, it is more able than other regulation theories to identify interest groups and to explain their behaviour in the regulatory process.

The economic theory of regulation also acknowledges that regulation is supplied to the market by the state in response to a demand which is often instigated by economic considerations, such as protection against competition or as a response to some crisis. Therefore, the creation, modification and demise of regulations can be analysed from the point of view of market behaviour. Rahman (1992, p. 311) also suggests that the form of regulation supplied to the market can be dictated by concerns to minimise bureaucracy and political and economic costs, such as the purchase of expertise. For instance, co-regulation between the state and professional bodies can emerge for these reasons. Mitnick (1980, pp. 83-84) argues that demand for, and hence the supply of, regulation will follow a five stage cyclical process over time and that crises frequently initiate the cycle. The stages of the cycle he proposes are: (a) the access stage, when issues are discussed; (b) the decision stage, when appropriate proposals are made; (c) the implementation stage; (d) the administration of regulations stage; and (e) the impacts stage, when the effects of regulations are assessed by the regulatory agency and modifications are made, if necessary. Mitnick argues that changes in regulation over time are a manifestation of the changing interests of politically effective groups. Watts (1977, pp. 65-67) suggests that demand for regulation, in the form of crises, might be purposively created to provide media entertainment or to provide political support on particular issues. Therefore, regulation might be supplied in response to a self-created crisis of politicians and other groups, such as the media.

Hypotheses suggested by economic regulation theory, which provide a framework for the conduct of further research into the statutory regulation of insurance companies, are proposed in the next section.

\section{Towards a framework for further research}

In the economic theory of regulation section of this paper it was noted that regulations and the regulatory process are driven by the economic criteria of demand and supply. This approach can thus provide researchers with a basis for the empirical study of insurance market regulation based on the following propositions:

1. Demand for regulation can arise because of some crisis, such as a corporate failure, or be instigated by the industry groups itself, for instance, to instigate barriers to entry ${ }^{16}$ or to secure subsidies (Mitnick, 1980). Therefore, it is hypothesided that:

$\mathrm{H}_{1}$ : Tightly regulated insurance markets have experienced some "crisis" and/or have policies which seek to protect the domestic insurance market from external competition.

16 In New Zealand, new entrants to the life insurance market must lodge a refundable deposit of NZ $\$ 500,000$ with the public trustee prior to authorisation. The industry lobby group, the Life Office Association (LOA), advocates that this deposit should be increased to NZ $\$ 3$ million. Arguably, this may be judged to be a barrier to the entry of small firms into the market. 
2. Groups will only participate in the regulatory process if the economic benefit exceeds the cost (Stigler, 1971). This implies that only interest groups with the economic means are likely to participate in the regulatory process and benefit from economies of scale in the lobbying process. Therefore, it is hypothesised that

$\mathrm{H}_{2}$ : Participant groups in tightly regulated insurance markets are better resourced and more active than equivalent groups in unregulated markets.

3. Smaller size groups face potentially lower transactions and information costs and so will tend to be more successful in influencing the regulatory process than larger size groups (Rahman, 1992). Furthermore, the potential rewards from regulation to members of such a small interest group could be substantial, for example, from the increased demand for professional services. Therefore, it is hypothesised that:

$\mathrm{H}_{3}$ : (Small) professional groups, such as the actuarial and accountancy professions, will be more successful than (larger), less knowledgeable interest groups, such as policyholders and investors, in influencing regulation.

4. Cartelization favours self-regulation, unless there is the chance that outside competition will threaten the cartel arrangement, in which case industry groups will have an incentive to lobby government for protective regulation (Posner, 1974). Therefore, it is hypothesised that:

$\mathrm{H}_{4}$ : Unregulated environments will be characterised by oligopoly markets with limited competition, whereas regulated markets will have larger numbers of firms engaged in greater competition.

5. The regulatory agency is staffed by bureaucrats and, like all participants, they have a self-interest in maintaining stringent controls on the regulated industry (Rahman, 1992). In the insurance industry the complexity of the issues will warrant the employment of costly professional specialists in the administrative bureaucracy. Therefore, it is hypothesised that:

$\mathrm{H}_{5}$ : Tightly regulated environments will have a costly bureaucracy to support it.

6. Some researchers (e.g. Watts and Zimmerman, 1978) suggest that the imposition of regulation can impose non-trivial costs on a firm. These additional costs can reduce the amount of resources available to finance management compensation, including perquisites. Consequently, management will actively participate and resource the lobbying process. Therefore, it is hypothesided that:

$\mathrm{H}_{6}$ : In tightly regulated insurance markets, lobby groups will be more highly funded per corporate member than in less regulated environments.

\section{Conclusion}

Alternative strands of regulation theory which provide explanations for the statutory regulation of insurance companies have been evaluated in this paper. The paper concludes that the economic theory of regulation offers the best framework for interpretative analyis and empirical research. This conclusion is based on the argument that the theory accommodates the more realistic view that regulation is the outcome of demand and supply, based 
on the concept of economic self-interest, rather than the less realistic notion that it reflects a pristine desire to maximise societal welfare. A significant contribution may lie in research directed to improving our understanding of the determinants of demand and supply for regulation in insurance markets and testing the hypotheses presented in this paper. Only when the nature and the role of the participants in the market for insurance company regulation are properly analysed can the process of regulation be fully understood.

\section{REFERENCES}

ADAMS, M. B. (1992, November 13), Life offices' self regulation insufficient protection National Business Review, pp. 54-55.

ASHTON, T. and St. JOHN, S. (1988), Superannuation in New Zealand: Averting the crisis. Wellington: Victoria University Press.

BARROW, G. E. and FERGUSON, D. G. R. (1984), A review of the law relating to insolvent life insurance companies and proposals for reform. Journal of the Institute of Actuaries, 111 (448), 229-257.

BATTEN, M. (1981, June), Insurance: A turbulent time for the industry. The Chartered Accountant in Australia, 51 (11), 66-68.

BEAVER, W. H. (1981), Financial reporting: An accounting revolution. Englewood Cliffs, NJ: Prentice Hall.

BOOSE, M. A. (1988), Agency costs and alternative theories as they apply to the management of life insurance companies. Unpublished Doctoral Thesis, University of Washington, U.S.A.

CAREW, E. (1987), New Zealand's money revolution: A comprehensive up-to-date guide to New Zealand's rapidly changing financial system. Wellington: Allen and Unwin/Port Nicholson Press.

COOPERS and LYBRAND (1988), International insurance industry guide. (4th Ed.). London: Lloyds of London Press Ltd.

DEMSETZ, H. and LEHN, K. (1985), The structure of corporate ownership: Causes and consequences. Journal of Political Economy, 93 (6), 1155-1177.

ELLIS, H. (1990), Government regulation of insurance companies. In Diacon, S. (Ed). A guide to insurance management (pp. 277-289): London: Macmillan Press Ltd.

FEROZ, E.H. (1987), Financial accounting standards setting: A social science perspective. Advances in Accounting, 5, 3-14.

Financial Reporting Bill 1991, (New Zealand), Wellington: Government Printing House.

Financial Services Act 1986 (U.K.), London: Her Majesty's Stationery Office.

FINSINGER, J. and PAULY, M. (1986), The economics of insurance regulation: A cross-national study, London: Mcmillan Press.

FISHER, H. F. and YOUNG, J. (1965), Actuarial practice of life insurance: A textbook for actuarial students. London: Cambridge University Press.

FORD, A. (1975), Life office returns to the Department of Trade and Industry. Journal of the Institute of Actuaries, 101, (415), 53-87. 
GAMSON, W. A. (1968), Power and discontent. Homewood, IL: The Dorsey Press.

GOODHART, C. (1988), The costs of regulation. In Seldon, A. (Ed). Financial regulation - or overregulation? (pp. 17-31). London: Institute of Economic Affairs.

GORMLEY, W. T. (1986), Regulatory issue networks in a federal system, Polity, 18, 595-620.

HARTE, G. and MACVE, R. (1991), The Vehicle and General Insurance Company Ltd ('V \& G'). In Taylor, P. and Turley, S. (Eds.). Case studies in financial reporting. London: Philip Allen.

HALL, J. (1987), Company offenders: Can we control them? A look at the Commercial Affairs Division. Unpublished Masters's Thesis, Department of Accountancy, Massey University, Palmerston North, NZ.

HOFSTEDE, G. (1980), Cultures consequences. New York: Sage Publications.

HUNT, G. (7 August, 1992a) Insurance commissioner will "improve market". National Business Review, p. 30.

HUNT, G. (21 August, 1992b), Crackdown on financial advisers. National Business Review, pp. 1-2.

Insurance Council of New Zealand, (April, 1991), Address: The Insurance Institute Journal, 14-16.

JOHNSTON, E. A. (1989), The appointed actuary. Journal of the Institute of Actuaries, 116 (463), $27-78$.

KELLNER, S. and MATHEWSON, G. F. (1983), Entry, size distribution, scale and scope economies in the life insurance industry. Journal of Business, 56 (1), 25-44.

KPMG Peat Marwick McLintock (1991), Insurance company reporting worldwide. London: Author.

KRUMPES, P. (14 May, 1992), Urgent need for consistency in methods. New Accountant, 5 (9), p. 24.

MAYERS, D. and SMITH, C. W. (1981), Contractual provisions, organizational structure, and conflict control in insurance markets. Journal of Business, 54 (3), 407-434.

MAYERS, D. and SMITH, C. W. (1988), Ownership structure across lines of property-casualty insurance. Journal of Law and Economics, 31 (2), 351-378.

MEIER, K. J. (1985), Regulation: Politics, bureaucracy and economics, New York: St. Martin's Press.

MEIER, K. J. (1991), The politics of regulation. The Journal of Risk and Insurance, 58 (4), 700-713.

MERINO, B. D. and NEIMARK, M. D. (1982), Disclosure regulation and public policy: A sociohistorical reappraisal. Journal of Accounting and Public Policy, 1 (1), 33-57.

MITNICK, B. M. (1980), The political economy of regulation: Creating, designing, and removing regulatory forms. New York: Columbia University Press.

MUELLER, D. C. (1976, June), Public choice: A survey. Journal of Economic Literature, 14, 395-433.

MUNCH, P. and SMALLWOOD, D. (1980), Solvency regulation in the property-liability insurance industry. Empirical evidence. Bell Journal of Economics, 24 (2), 261-282.

New Zealand Department of Statistics (1991), New Zealand Pocket Digest of Statistics. Wellington: Government Printing House.

New Zealand Financial Reporting Act 1993. Wellington: Government Printer.

NOBBS, R. (1983), The development of friendly societies and life assurance in Australia. Journal of the Institute of Actuaries, 110 (447), 457-466.

NOLL, R. G. and OWEN, B. M. (1983), The political economy of deregulation. Washington: American Enterprise Institute.

PEIRSON, G. and RAMSAY, A. L. (1983, November), A review of the regulation of financial reporting in Australia. Companies and Securities Law Journal, 1, 286-300.

PELTZMAN, S. (1976), Towards a more general theory of regulation, Journal of Law and Economics, $19,211-240$ 
POSNER, R. A. (1974), Theories of economic regulation. The Bell Journal of Economics and Management Science, 5 (2), 335-358.

PRAETZ, P. D. (1983), The effect of size and other economic factors on the expense rate behaviour of U.K. life insurance companies, Journal of the Institute of Actuaries, 10 (2), 383-388.

RAHMAN, A. R. (1992), The Australian Accounting Standards Review Board. The establishment of its participative review process. New York: Garland Publishing.

REAGAN, M. D. (1987), Regulation: The politics of policy. Boston: Little Brown.

REID, C. (1988, October), GAAP accounting for life companies in New Zealand. Paper presented at the New Zealand Society of Actuaries conference on life office financial management, Wellington.

ROBERTS, K. (1991, July), Strategies for the insurance industry. Paper presented at the Insurance Institute of New Zealand Conference, Wellington.

ROURKE, F. E. (1984), Bureaucracy, politics and public policy. Boston: Little Brown.

SMITH, C. W. (1986), On the convergence of insurance and finance research. Journal of Risk and Insurance, 53 (4), 693-717.

STIGLER, G. J. (1971), The theory of economic regulation. The Bell Journal of Economics and Management Science, 2 (3), 3-21.

TAPP, J. (1986), Regulation of the U.K. insurance industry, in Finsinger, J. and Pauly, M. V. (Eds.). The economics of insurance regulation: A cross-national study, (pp. 27-61). London: Macmillan Press Ltd.

TINKER, A. (1984), Theories of the state and the state of accounting: Economic reductionism and political voluntarism in accounting regulation theory. Journal of Accounting and Public Policy, 3 (1), 55-74.

WATTS, R. L. (1977), Corporate financial statements, a product of the market and political processes. Australian Journal of Management, 2 (1), 53-75.

WATTS, R. L. and ZIMMERMANN, J. L. (1978), Towards a positive theory of the determination of accounting standards. The Accounting Review, 53 (1), 112-134.

WATTS, R. L. and ZIMMERMANN, J. L. (1986), Positive Accounting Theory. Englewood Cliffs, NJ: Prentice Hall.

WILSON, J. Q. (1974), The politics of regulation. In McKie, J. W. (Ed.), Social responsibility and the business predicament, (pp. 135-168), Washington DC: The Brookings Institution.

WOOD, D. (1991), Accounting practices of life offices in New Zealand. Paper presented at the Ernst and Young seminar on financial reporting in the life insurance industry: Current trends and developments, Wellington. 